\title{
The Evaluation of Sodium Lauryl Sulphate in Toothpaste on Toxicity on Human Gingiva and Mucosa: A 3D in vitro Model
}

\section{Bart Vande Vannet ${ }^{1 *}$, Bart De Wever ${ }^{2}$, Els Adriaens ${ }^{3}$, Frans Ramaeckers ${ }^{2}$ and Peter Bottenberg ${ }^{4}$}

${ }^{1}$ Department of Orthodontics, Free University of Brussels, Laarbeeklaan 103, 1090 Brussels, Belgium

${ }^{2}$ Department of Molecular Cell Biology, GROW, University of Maastricht, The Netherlands

${ }^{3}$ Lab Pharmaceutical Technology, University of Ghent, Gent, Belgium

${ }^{4}$ Department of Restorative and Preventive Dentistry, Free University of Brussels, Laarbeeklaan 103, 1090 Brussels, Belgium

\begin{abstract}
Five different commercial toothpaste formulations were labeled as $A, B, C, D$ and $E$ and evaluated for toxicity in vitro using reconstituted human oral and gingival mucosa cultures. Toothpastes $A, D$ and $E$ contained sodium lauryl sulphate (SLS) while toothpastes $B$ and $C$ did not. All toothpastes contained fluoride in different quantities. Tissue viability (MTT), tissue morphology (LM and TEM) and release of pro-inflammatory mediator IL-1 $\alpha$ were evaluated. For gingival mucosa, topical exposure of toothpastes did not affect MTT values. Examination of oral mucosa however, showed that toothpastes B, E and D induced a significant loss of viability after $1 \mathrm{~h}(49.2 \%, 55.5 \%$ and $78.4 \%$ respectively) $(p<0.05)$. After 3 hours toothpaste $B$ demonstrated a $51.4 \%$ loss of viability whereas tissue viability for toothpastes $D$ and $E$ dropped to $11.1 \%$ and $4.5 \%$ respectively. The release of pro-inflammatory mediator IL-1a showed that only gingival mucosa tissues exposed to toothpaste $D$ and $E$ showed a marked increase of IL-1 $\alpha$ after 1 hour, and toothpaste $A, D$ and $\mathrm{E}$ after $3 \mathrm{~h}$ exposure. Oral mucosa tissue exposed for $1 \mathrm{~h}$ resulted in increased levels of IL-1 $\mathrm{\alpha}$ for toothpastes A, B, $\mathrm{D}$ and $\mathrm{E}$, which became more important at $3 \mathrm{~h}$. Morphological analysis of the oral mucosa demonstrated partial necrosis after exposure to toothpastes A, B and C, and severe necrosis to D and E. MTT cannot be used as single toxicity parameter and should be confirmed by histology. Both in vitro oral and gingival mucosa models are suitable to evaluate the toxicity of toothpaste formulations. The presence of SLS in toothpaste formulations is presumably responsible for the toxicity observed in vitro. MTT, IL-1 $\alpha$ release and morphology were affected by the SLS containing toothpastes A, D and $\mathrm{E}$. These observations confirm clinical inflammatory effects of SLS in oral care products often reported in literature.
\end{abstract}

Keywords: Oral mucosa; Gingival mucosa; Toothpaste; Fluoride; MTT; 3D cell cultures; Toxicity; Sodium lauryl sulphate

\section{Introduction}

Maintaining good oral hygiene is a very important issue in everyday life and especially during an orthodontic treatment. The term 'oral hygiene products' is recent but there is historical evidence dating back at least 6000 years that formulations and recipes existed to benefit oral and dental health [1]. Throughout centuries, most toothpowders, toothpastes and mouth rinses appeared to have been formulated for cosmetic reasons including tooth cleaning and breathe freshening rather than the control of dental and periodontal diseases [2]. During the last century, toothpastes became less abrasive [3] and a set of safety standards were developed [4-6].

By virtue of common usage, toothpastes are the ideal vehicles for plaque control agents. A number of ingredients are being used to formulate toothpaste and each has a role in either influencing the consistency and stability of the product or its function $[7,8]$. These ingredients include abrasives, detergents, thickeners, sweeteners, humectants, flavours and active ingredients $[9,10]$. The most common detergent used in toothpaste is the anionic compound sodium lauryl sulfate (SLS), which imparts the foam and 'feel' properties to the product. Additionally, detergents may help dissolve active ingredients and SLS has both antimicrobial and plaque inhibitory properties [11]. In fact SLS was shown to have moderate substantivity measured at between 5 and 7 hours and plaque inhibitory action. However SLS also induces prominent changes in the histological structure of animal cheek pouch epithelium. These changes include hyperkeratosis, hypergranulosis, acanthosis and varying degrees of basal hyperplasia, all of which result in a significant increase in epithelial thickness [12]. The known untoward side effects of SLS in the human oral cavity are inflammation and desquamation of oral mucosa [13-15].

The aim of the present study was to investigate whether the presence of SLS in marketed toothpastes would alter the morphology and biochemical properties (viability and inflammatory cytokine release) of human 3D cell cultures. Since tissue cell cultures are generally recognised in the literature as being a sensitive method of assaying the cytotoxic potential of test materials [16-18], the objective of this experiment was to measure the toxicity of 5 marketed toothpastes on a reconstituted human oral and gingival epithelium model. The working hypothesis was that toothpastes containing SLS showed more negative effects on cell cultures.

\section{Materials and Methods}

A complete synopsis of the experimental protocol is shown as flowchart in Figure 1.

\section{Test materials}

Toothpastes were blinded and labelled as A, B, C, D and E (Table 1). Toothpastes A, D and E contained SLS while toothpastes B and C did not. They all did contain fluoride. A detailed listing of the ingredients in each toothpaste is listed in Table 1. In order to simulate the oral condition (dilution by saliva), toothpastes were mixed with water in 1:2 ratios to produce a $30 \%$ toothpaste slurry. As positive control, SLS

*Corresponding author: Bart Vande Vannet, DDS, MSc, PhD, Professor, Vrije Universiteit Brussel, Orthodontie, Laarbeeklaan 103, Brussel, 1090, Belgium, Tel: +3224774908; Fax: +3224774908; E-mail: bart.vande.vannet@vub.ac.be

Received July 08, 2015; Accepted July 28, 2015; Published August 09, 2015

Citation: Vannet BV, De Wever B, Adriaens E, Ramaeckers F, Bottenberg P (2015) The Evaluation of Sodium Lauryl Sulphate in Toothpaste on Toxicity on Human Gingiva and Mucosa: A 3D in vitro Model. Dentistry 5: 325. doi:10.4172/2161 1122.1000325

Copyright: (c) 2015 Vannet BV, et al. This is an open-access article distributed under the terms of the Creative Commons Attribution License, which permits unrestricted use, distribution, and reproduction in any medium, provided the original author and source are credited. 


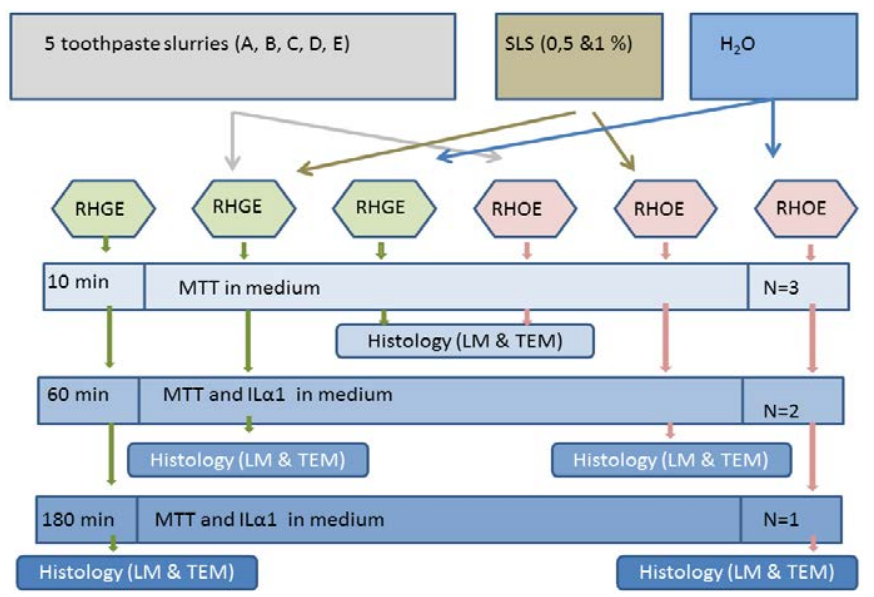

Figure 1: Synopsis of Experimental Protocol.

\begin{tabular}{|c|c|c|}
\hline Code & Toothpaste & Ingredients \\
\hline A & $\begin{array}{l}\text { Thera-med Original } \\
\text { Batch number: } \\
0520741 \\
\text { Schwartzkopf and } \\
\text { Henkel, Dusseldorf, } \\
\text { imp. B-1080 Brussels, } \\
\text { Nieuwegein }\end{array}$ & $\begin{array}{l}\text { Aqua, Hydrated Silica, Glycerin, Sorbitol, PEG- } \\
32 \text {, Sodium lauryl sulfate, Aroma, Cellulose gum, } \\
\text { Trisodium phosphate, Disodium phosphate, } \\
\text { Sodium saccharin, Zinc sulfate, Sodium } \\
\text { benzoate, } \mathrm{Cl} 14720, \mathrm{Cl} 42090, \mathrm{Cl} 69800, \mathrm{Cl} \\
42090 \text {. Contains Sodium fluoride (1450 ppm F-) }\end{array}$ \\
\hline B & $\begin{array}{l}\text { Elmex } \\
\text { Batch number: } \\
\text { 4385G2 } \\
\text { Johnson and Johnson, } \\
\text { GABA B.V., Postbus } \\
1039,1039 \text { BA, } \\
\text { Almere }\end{array}$ & $\begin{array}{l}\text { Aqua, Hydrated Silica, Sorbitol, Hydroxy ethyl } \\
\text { cellulose, Aroma, Titanium dioxide, Saccharin } \\
\text { Contains Olafluor (1250 ppm F-), }\end{array}$ \\
\hline C & $\begin{array}{l}\text { Zendium Classic } \\
\text { Batch number: } \\
125111 ; 152301 ; \\
7304742 \\
\text { Kortman intradal SA, } \\
\text { Sara Lee Hand BC, } \\
\text { Belgium, } 1702 \text { Groot- } \\
\text { Bijgaarden }\end{array}$ & $\begin{array}{l}\text { Aqua, Hydrated silica, Glycerin, Sorbitol, } \\
\text { Steareth-30, Carrageenan, Aroma, Titanium } \\
\text { dioxide, Disodium phosphate, Citric acid, } \\
\text { Sodium benzoate, Sodium saccharin, Potassium } \\
\text { thiocyanate, Glucose oxidase, Amyloglucosidase, } \\
\text { Lactoperoxidase } \\
\text { Contains Sodium fluoride ( } 1100 \text { ppm F-) }\end{array}$ \\
\hline D & $\begin{array}{l}\text { Signal Integral } \\
\text { Batch number: } \\
\text { 405671WB Unilever, } \\
\text { Lever Fabergé } \\
\text { Belgium, Unibel N.V., } \\
1190 \text { Vorst }\end{array}$ & $\begin{array}{l}\text { Aqua, Hydrated Silica, Sorbitol, Calcium } \\
\text { Carbonate, Sodium Lauyl Sulfate, Sodium } \\
\text { Monofluorphosphate, Aroma, Sodium Fluoride, } \\
\text { PEG-32, Cellulose Gum, Methylparaben, } \\
\text { Propylparaben, CL } 73360 \\
\text { Contains eucalyptus-extracts and Sodium fluoride } \\
(1450 \text { ppm F-) }\end{array}$ \\
\hline$E$ & $\begin{array}{l}\text { Colgate Blue Minty Gel } \\
\text { Batch number: } \\
4146 I T 10305 \\
\text { Colgate-Palmolive, } \\
1160 \text { Brussel, } 4041 \\
\text { Liege }\end{array}$ & $\begin{array}{l}\text { Aqua, Hydrated Silica, Glycerin, Sorbitol, PEG- } \\
12 \text {, Sodium lauryl sulfate, Aroma, Cellulose } \\
\text { gum, Sodium saccharin, Dicalcium phosphate } \\
\text { dihydrate, } \mathrm{Cl} 42090, \mathrm{Cl} 42090 \\
\text { Contains Sodium fluoride } 0.1 \%\left(450 \mathrm{ppm} \mathrm{F}^{-}\right) \text {, } \\
\text { Sodium monofluorophosphate } 0.76 \%(1000 \mathrm{ppm} \\
\left.\mathrm{F}^{-}\right)\end{array}$ \\
\hline
\end{tabular}

Table 1: Ingredients of the tested toothpastes (as mentioned by manufacturers).

solutions $(0.5$ and $1 \% \mathrm{w} / \mathrm{v}$ in water) were used and water is used as negative control.

\section{Tissue culture models and experimental treatment}

Commercially available $0.5 \mathrm{~cm}^{2}$ inserts containing reconstituted human oral epithelium (RHOE) and reconstituted human gingival epithelium (RHGE) were obtained by culturing either human oral epithelial cells (TR-146 cell line of oral squamous carcinoma) or human gingival cells (primary cells from a gingival epithelial biopsy) on polycarbonate culture inserts lifted to the air-liquid interface for 7 days (SkinEthic Laboratories, Nice, France). Prior to testing, the RHOE and RHGE inserts were placed onto $300 \mu \mathrm{l}$ of maintenance medium. $30 \mu \mathrm{l}$ of a $30 \%$ dilution of each toothpaste product (A, B, C, D and E) was applied onto triplicate cultures which were incubated at $37^{\circ} \mathrm{C}$, $5 \% \mathrm{CO}_{2}$ for 10 minutes, $1 \mathrm{~h}$ and $3 \mathrm{~h} .30 \mu \mathrm{l}$ of water (negative control) was applied in parallel onto triplicate cultures and $30 \mu \mathrm{l}$ of a 0.5 or $1 \%$ SLS solution was applied as positive controls, also in triplicate. For each condition, at the end of the test period, duplicate cultures were placed into appropriated labelled wells for MTT cytotoxicity testing. Additionally, the medium underneath each culture was collected and stored at $-20^{\circ} \mathrm{C}$ for extracellular release of pro-inflammatory mediators IL-1 $\alpha$.

\section{MTT assay procedure}

The MTT assay was performed by placing the treated $0.5 \mathrm{~cm}^{2}$ inserts containing RHOE and RHGE in wells containing $0.3 \mathrm{ml}$ of 0.5 $\mathrm{mg} / \mathrm{ml}$ MTT solution (Sigma-Aldrich St. Louis, MO, USA solution lot no. $02010 \mathrm{AD} 0602$ ). All tissues were then incubated at $37^{\circ} \mathrm{C}$ for $3 \mathrm{~h}$. For qualitative evaluation of cell viability, after 30 minutes incubation, the colour of each culture was noted. Negative control cultures have to be dark blue colour, proof of cell's viability. Positive control cultures have to be blue/white, evidence of cell death. For quantitative evaluation of cell viability extraction was performed at room temperature in $1.5 \mathrm{ml}$ of isopropanol for a minimum of $1.5 \mathrm{~h}$, by gentle shaking. $200 \mathrm{ml}$ of extracts were transferred in a 96 well plate and OD was measured at 570 $\mathrm{nm}$ by a spectrophotometer (Dynex Technology, Chantilly, Virginia USA). Reference filter: $690 \mathrm{~nm}$.

$$
\% \text { of viability }=\left(\mathrm{DO}_{570} \mathrm{~nm} \text { sample } / \mathrm{DO}_{690} \mathrm{~nm} \text { control }\right) \times 100 .
$$

\section{IL-1a quantification measurements}

The amount of pro-inflammatory mediator IL- 1 a was quantified in the medium underneath the RHOE and RHGE tissues by quantitative sandwich immunoassay technique (Quantikine Human IL-1a, R\&D Systems, UK, Ref DLA50, lot 207423). After topical application, the cultures were incubated on $0.3 \mathrm{ml}$ of defined medium for $1 \mathrm{~h}$ and 3 h. Conditioned media were collected and kept frozen for cytokine quantification. The inflammatory mediators released in these conditioned media were then quantified using ELISA kits, specifically for each type of mediator to be measured. For each sample and standard, $200 \mu \mathrm{l}$ of the collected medium was incubated in the pre-coated 96well plate wells for 2 hours at room temperature. After washing, $200 \mu \mathrm{l}$ of IL-1a conjugate was added and the plate was consequently incubated for 60 minutes. After incubation, all wells were washed 3 times and $200 \mu \mathrm{l}$ of $\mathrm{TMB} / \mathrm{H}_{2} \mathrm{O}_{2}$ was added. Following incubation for 20 minutes, the reaction was stopped by adding $50 \mu \mathrm{l}$ of $2 \mathrm{~N} \mathrm{H}_{2} \mathrm{SO}_{4}$. All wells were consequently read in a spectrophotometer (Dynex Technology, Chantilly, Virginia, USA) at $450 \mathrm{~nm}$ (ref filter $570 \mathrm{~nm}$ ). The concentrations of IL-1 $\alpha$ present in the samples were calculated on the basis of a calibration curve. In all cases, duplicate measurements were performed for each sample.

\section{Morphology evaluation by light and electron microscopy}

All remaining manipulations were hereafter performed at room temperature. For each condition, at the end of the test period, one of the triplicate cultures was cut in half. One moiety of the tissue was fixed in a $10 \%$ formalin solution and later embedded in paraffin. Four micron vertical sections were stained with hematoxy/eosin and photographed under a light microscope. The sections were evaluated with the light 
microscope Leica ${ }^{\circledR}\left(\mathrm{DMR}^{\circledR}\right.$, Wetzlar, Germany) at 10x, 20x, 40x and $63 x$ magnification.

For Transmission Electron microscopy (TEM) (Tecnai 10 Philips ${ }^{\circ}$ Eindhoven, The Netherlands), the second half of the tissues were fixed with a solution containing $1.5 \%$ glutaraldehyde in cacodylate buffer 0.1 $\mathrm{M}$ and sucrose $0.1 \mathrm{M}\left(\mathrm{pH} \mathrm{7.4)}\right.$ at $4^{\circ} \mathrm{C}$. After 30 minutes treatment, the solution was removed and $3 \mathrm{ml}$ of osmium tetroxide $\left(\mathrm{OsO}_{4}\right) 1 \%$ in 0.1 $\mathrm{M}$ cacodylate buffer was added at $4^{\circ} \mathrm{C}$ [19]. $1 \mathrm{~h}$ later the cultures were rinsed three times with distilled water. All remaining manipulations were thereafter performed at room temperature. The tissues were stained with $3.5 \%$ of uranyl acetate in water for 10 minutes. After three short rinses with distilled water, followed by a dehydratation in an alcohol series, dehydratation was stopped by transferring the tissues in pure ethanol two times for 10 minutes, followed by one time for 20 minutes. The final step consisted of dipping the biopsies and cell cultures into a mixture of ethanol $100^{\circ}$ with Epon resin (Polysciences, Eppelheim, Germany) 1/1 for 60 minutes. The biopsies and cell cultures were consequently immersed overnight in Epon at room temperature and the next day, the filter was carefully cut out, imbedded in fresh Epon and cured in the oven at $60^{\circ} \mathrm{C}$ for 2 days. Sections were made with an ultramicrotone Ultracut (Reichert, Wien, Austria).

\section{Statistical analysis}

The effect of the different treatments and the treatment period on the viability and the IL- $1 \alpha$ release for both the RHOE and RHGE were assessed with a two-way ANOVA. The normality of the residuals was analysed with a Kolmogorov-Smirnov test and the homogeneity of the variances was tested with the Levene's test. When the variances were found not to be equal the data were log-transformed. To further compare the difference between the treatments for each time period and to evaluate the time effect for each treatment a Bonferoni post hoc test with a significance level of $\mathrm{p}<0.05$ was used. The statistical analysis was performed using SPSS version 12.0.

\section{Results}

\section{Evaluation of cell viability (MTT test)}

The influence of the toothpastes on the viability of the RHOE and RHGE in function of time is shown in Table 2. For gingival mucosa, topical exposure of toothpastes did not affect MTT values. Examination of oral mucosa however, showed that the toothpastes B, E and D induced a significant loss of viability after $1 \mathrm{~h}$ (respectively $49.2 \%, 55.5 \%$ and $78.4 \%, \mathrm{p}<0.05$ ). After $3 \mathrm{~h}$, toothpaste B demonstrated a loss of viability of $51.4 \%$, whereas tissue viability for toothpaste $\mathrm{D}$ and $\mathrm{E}$ dropped to $11.1 \%$ and $4.5 \%$ respectively. For the RHGE all the toothpastes showed a viability that was statistically comparable with the negative controls after a $3 \mathrm{~h}$ treatment. However, for the RHOE, toothpastes B, D and E induced a decrease of the viability after $1 \mathrm{~h}$ and for toothpastes $\mathrm{D}$ and $\mathrm{E}$ longer treatment resulted in a further decrease of the viability that was statistically significant from the negative control after $3 \mathrm{~h}$. Toothpastes $\mathrm{A}$ and $\mathrm{C}$ did not affect the viability of the RHOE, after $3 \mathrm{~h}$ the viability was still comparable with the negative control. For both the RHOE and RHGE the positive controls (SLS $0.5 \%$ and $1 \%$ ) resulted in a time and concentration dependent decrease of the viability.

For both models all negative control treated tissues were coloured blue and all positive control treated tissues coloured white after 1 hour. All tested toothpastes showed a statistically different toxicity profile for each tissue type $(\mathrm{p}<0.001)$.

\section{Release of inflammatory mediator IL-1a}

Table 3 shows the release of the inflammatory mediator IL-1 $\alpha$ for the different treatments in function of time. For the RHOE toothpastes A, B, D and E induced a significantly increase of IL- $1 \alpha$ after 60 minutes when compared to the negative control. The IL-1 $\alpha$ release increased significantly for toothpastes A, C, D and E although for toothpaste $\mathrm{C}$ the release after $3 \mathrm{~h}$ was statistically lower when compared to the other toothpastes and to the positive controls. Toothpastes B and C did not affect the IL- $1 \alpha$ release of the RHGE, after $3 \mathrm{~h}$ the levels were

\begin{tabular}{|c|c|c|c|}
\hline \multirow{2}{*}{ Treatment } & \multicolumn{3}{|c|}{ Viability MTT (\%) ${ }^{1}$} \\
\hline & $10 \mathrm{~min}$ & $60 \min$ & $180 \mathrm{~min}$ \\
\hline \multicolumn{4}{|c|}{ RHOE } \\
\hline Control & $100.0 \pm 1.4^{a}$ & $100.0 \pm 0.6^{a, b}$ & $100.0 \pm 2.7^{a, b}$ \\
\hline SLS $0.5 \% *$ & $93.2 \pm 2.3^{a}$ & $44.9 \pm 6.4^{\mathrm{c}, \mathrm{d}}$ & $29.4 \pm 3.7^{c}$ \\
\hline SLS $1 \% *$ & $81.4 \pm 3.4^{a}$ & $30.3 \pm 0.9^{d}$ & $3.5 \pm 1.7^{e}$ \\
\hline A & $109.5 \pm 3.7^{a}$ & $106.4 \pm 5.4^{a}$ & $103.1 \pm 14.4^{a}$ \\
\hline$B^{*}$ & $104.7 \pm 2.6^{a}$ & $49.2 \pm 3.1^{b, c, d}$ & $51.4 \pm 21.1^{b, c}$ \\
\hline C & $109.3 \pm 2.1^{\mathrm{a}}$ & $92.2 \pm 1.3^{\mathrm{a}, \mathrm{b}}$ & $95.9 \pm 1.5^{\mathrm{a}, \mathrm{b}}$ \\
\hline$D^{*}$ & $121.8 \pm 9.8^{\mathrm{a}}$ & $78.4 \pm 35.4^{\mathrm{a}, \mathrm{b}, \mathrm{c}}$ & $11.1 \pm 5.1^{d}$ \\
\hline$E^{*}$ & $110.8 \pm 6.9^{a}$ & $55.6 \pm 10.3^{a, b, c, d}$ & $4.5 \pm 0.4^{\mathrm{e}}$ \\
\hline \multicolumn{4}{|c|}{ RHGE } \\
\hline Control & $100.0 \pm 1.8^{\mathrm{a}, \mathrm{b}, \mathrm{c}}$ & $100.0 \pm 6.9^{a}$ & $100.0 \pm 3.2^{\mathrm{a}}$ \\
\hline SLS $0.5 \% *$ & $87.4 \pm 5.7^{\mathrm{b}, \mathrm{c}}$ & $40.8 \pm 0.8^{b}$ & $33.1 \pm 1.5^{b}$ \\
\hline SLS $1 \% *$ & $82.8 \pm 1.4^{c}$ & $28.0 \pm 4.1^{c}$ & $4.6 \pm 0.2^{\mathrm{c}}$ \\
\hline A & $100.4 \pm 3.2^{\mathrm{a}, \mathrm{b}, \mathrm{c}}$ & $98.9 \pm 6.0^{\mathrm{a}}$ & $102.4 \pm 2.8^{\mathrm{a}}$ \\
\hline$B$ & $103.2 \pm 3.0^{\mathrm{a}, \mathrm{b}}$ & $103.3 \pm 1.7^{\mathrm{a}}$ & $95.9 \pm 6.1^{\mathrm{a}}$ \\
\hline C & $97.8 \pm 4.7^{\mathrm{a}, \mathrm{b}, \mathrm{c}}$ & $96.5 \pm 2.7^{a}$ & $106.2 \pm 14.6^{a}$ \\
\hline D & $101.9 \pm 5.2^{\mathrm{a}, \mathrm{b}, \mathrm{c}}$ & $98.1 \pm 0.7^{\mathrm{a}}$ & $110.3 \pm 2.8^{a}$ \\
\hline$E$ & $108.5 \pm 0.3^{a}$ & $102.1 \pm 7.4^{\mathrm{a}}$ & $100.4 \pm 10.4^{a}$ \\
\hline
\end{tabular}

${ }^{1}$ Values represent the mean $\pm S D, n=2$

a,b,c,d,e Within each time period means with the same superscript are not significantly different from each other.

*This treatment resulted in a significant decrease in viability in function of time

Table 2: Influence of the different toothpastes on the viability in function of time.

\begin{tabular}{|c|c|c|c|c|c|c|}
\hline \multirow{2}{*}{ Treatment } & \multicolumn{6}{|c|}{ IL-1 $\alpha^{1}$} \\
\hline & \multicolumn{3}{|c|}{$60 \mathrm{~min}$} & \multicolumn{3}{|c|}{$180 \mathrm{~min}$} \\
\hline \multicolumn{7}{|c|}{ RHOE } \\
\hline Control & 1.0 & \pm & $0.0^{\mathrm{a}}$ & 1.0 & \pm & $0.0^{\mathrm{a}}$ \\
\hline SLS $0.5 \% *$ & 36.0 & \pm & $3.9^{c}$ & 66.6 & \pm & $7.2^{\mathrm{d}}$ \\
\hline SLS $1 \% *$ & 27.6 & \pm & $10.8^{c}$ & 63.3 & \pm & $7.1^{d}$ \\
\hline$A^{*}$ & 8.0 & \pm & $0.4^{b}$ & 23.9 & \pm & $2.6^{c}$ \\
\hline B & 27.7 & \pm & $12.9^{c}$ & 25.1 & \pm & $7.7^{c}$ \\
\hline$C^{*}$ & 1.1 & \pm & $0.3^{a}$ & 9.0 & \pm & $3.3^{b}$ \\
\hline$D^{*}$ & 11.7 & \pm & $2.2^{\mathrm{b}}$ & 39.4 & \pm & $2.0^{c, d}$ \\
\hline$E^{*}$ & 8.4 & \pm & $3.5^{b}$ & 35.2 & \pm & $7.9^{\mathrm{c}, \mathrm{d}}$ \\
\hline \multicolumn{7}{|c|}{ RHGE } \\
\hline Control & 1.1 & \pm & $0.2^{\mathrm{a}}$ & 1.3 & \pm & $0.1^{a}$ \\
\hline SLS $0.5 \%$ & 50.5 & \pm & $21.5^{\mathrm{b}}$ & 68.9 & \pm & $14.1^{\mathrm{c}}$ \\
\hline SLS $1 \%$ & 34.6 & \pm & $19.1^{\mathrm{b}}$ & 65.5 & \pm & $9.7^{c}$ \\
\hline$A^{*}$ & 3.2 & \pm & $1.7^{\mathrm{a}}$ & 15.0 & \pm & $4.0^{b}$ \\
\hline B & 3.0 & \pm & $2.7^{\mathrm{a}}$ & 2.1 & \pm & $0.7^{a}$ \\
\hline C & 2.6 & \pm & $1.2^{\mathrm{a}}$ & 1.5 & \pm & $0.1^{\mathrm{a}}$ \\
\hline $\mathrm{D}$ & 18.7 & \pm & $12.3^{b}$ & 28.5 & \pm & $13.8^{\mathrm{b}, \mathrm{c}}$ \\
\hline$E$ & 28.7 & \pm & $18.3^{b}$ & 57.4 & \pm & $13.7^{\mathrm{b}, \mathrm{c}}$ \\
\hline
\end{tabular}

${ }^{1}$ Values represent the mean $\pm S D, n=3$

$a, b, c, d$ Within each time period means with the same superscript are not significantly different from each other.

*This treatment resulted in a significant increase of IL-1a in function of time

Table 3: Influence of the different toothpastes on the IL-1 $1 \alpha$ release in function of time. 
still comparable with the negative control. Toothpaste A induced a significant increase after $3 \mathrm{~h}$, whereas toothpaste $\mathrm{D}$ and $\mathrm{E}$ resulted in a significant increase after $1 \mathrm{~h}$ when compared to the negative controls. The positive controls induced a significantly increase of IL- $1 \alpha$ after $1 \mathrm{~h}$ in comparison with the negative control for both the RHOE and RHGE. Cell type was not significant but showed different results for different tested products.

\section{Histology}

For each test material, at the end of each test period, half tissue was fixed in a $10 \%$ balanced formalin solution and embedded in paraffin for LM, the other half in Epon for TEM. The histopathological interpretation was peered by 2 patho-anatomologist who came to the same conclusions $(\mathrm{p}<0.05)$. Histopathological examination of LM of the in vitro oral and gingival epithelium model is classified as follows [20-22]:

- No irritation (NI): constant thickness of the epithelium, regular and compact shape, cells attached to the others;

- Mild irritation (MiI): minimal changes with slight oedema;

- Moderate irritation (MoI): beginning spongiosis in upper layers and architectural atrophy, cellular irregularity;

- Severe irritation (SI): disintegration of the upper cell-layers, spongiosis, cellular necrosis, loss of cellular junction in basic layer.

The results of both cell cultures are presented as colour slides. Negative control scored NI (T1-T3), Positive control SI (T1-T3) as well as toothpastes D and E (Figure 2) on RHOE. MiI is seen for tooth paste $\mathrm{A}, \mathrm{B}$ and $\mathrm{C}$ after $1 \mathrm{~h}$ partial necrosis in all toothpastes on RHOE. The results of TEM showed similar effects with severe disturbances at ultrastructural level of toothpaste A, D and $\mathrm{E}$ after $1 \mathrm{~h}$ and $3 \mathrm{~h}$ both on RHOE and RHGE (Figure 3). Apoptosis and necrosis is observed after 1 hour and 3 hours in the latter toothpaste samples (Figure 3 ).

\section{Discussion}

Vacuolisation was reported in previous studies on monolayer and confirms the histological results in the present study [13].

The 5 marketed toothpastes were evaluated blind. A 30\% solution was chosen in order to simulate normal use of toothpaste as half of the amount is washed or rinsed after the first application. The amount of $30 \%$ dilution was considered as the actual used portion in vivo. It is important to note that, with saliva in the mouth, the final dilution of toothpaste encountered during brushing is about one-third [23]. All toothpastes contained a fluoride formulation. However, the effect of fluoride was not considered although previous in vitro studies indicated that sodium fluoride can be toxic to oral mucosal fibroblasts in vitro by its inhibition of protein synthesis, mitochondrial function and depletion of cellular ATP $[24,25]$. Using the gingival epithelial tissues, only an effect was noticed at the level of IL-1 $\alpha$ release. No toxicity was measured with MTT. Based on this end point, the toothpastes could by ranked in order of increasing irritation potency as follows:

\section{(Colgate)}

$\mathrm{C}($ Zendium $)=\mathrm{B}($ Elmex $)<\mathrm{A}($ Thera-Med $)<\mathrm{D}($ Signal $)<\mathrm{E}$

Using the oral epithelial tissues an effect of the toothpastes was noticed on the viability, the IL- $1 \alpha$ release (less discriminative) and on the histology. Based on the different endpoints the following rank order of increasing irritation potency could be established:
$\mathrm{C}($ Zendium $)<\mathrm{A}(\text { Thera-Med })^{*}<\mathrm{B}($ Elmex $)<\mathrm{D}($ Signal $) \sim \mathrm{E}$ (Colgate)

"For Thera-Med high viability was observed after $3 \mathrm{~h}$, however the tissue was described as necrotic.

\section{Conclusion}

Based on the histological findings and the statistical interpretation of the quantitative evaluation of the biochemical endpoints, the following conclusions could be drawn. The RHOE model is more sensitive compared to RHGE. This is due to the morphological differences in the tissue differentiation which is far more advanced in the RHGE, featuring the presence of a thin stratum corneum, little parakeratosis and few or no granular cell layers, opposite to the less differentiated RHOE. False negative results are obtained when tissue viability (MTT assay) is being used as a single end point to evaluate

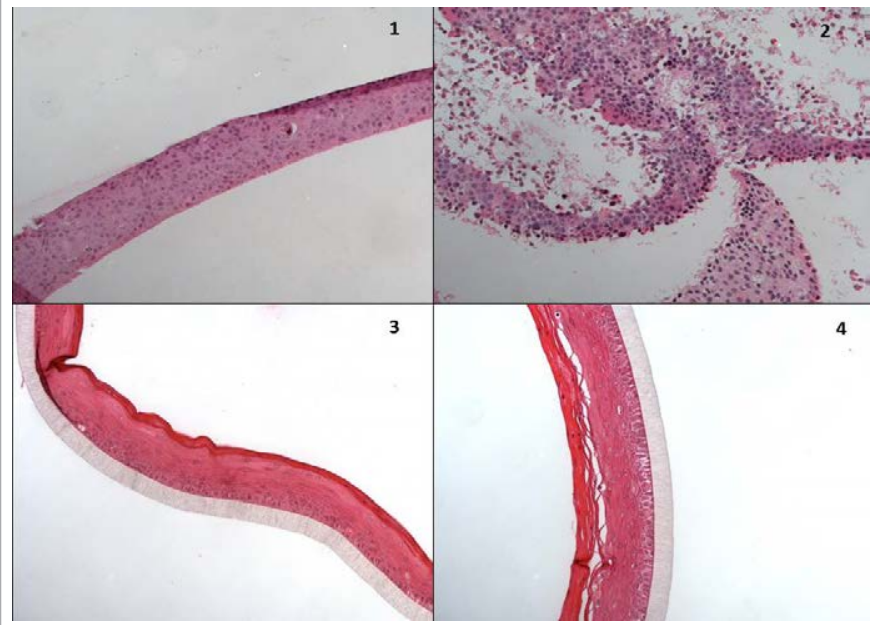

Notice the dramatic effects of toothpaste $E$ on RHOE.

Figure 2: Light microscopy (x40) effects of toothpaste $E$ on RHOE (2) severe irritant (SI) and RHGE (4) severe irritant (SI) compared to non-treated cultures RHOE (1) (NI) and RHGE (3) (NI) both at $180 \mathrm{~min}$.

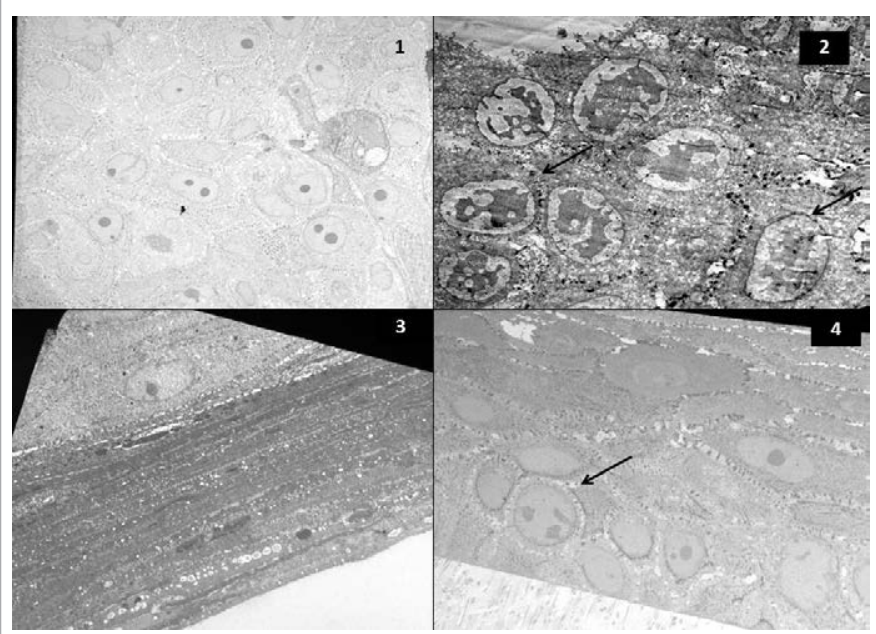

Notice the dramatic effects of toothpaste $\mathrm{E}$ on RHOE on ultrastructural level marked with necrotic and apoptotic cells (arrows).

Figure 3: TEM (x6200) effects of toothpaste E on RHOE (2) and RHGE (4) compared to non-treated cultures RHOE (1) and RHGE (3) both at $180 \mathrm{~min}$. 
Citation: Vannet BV, De Wever B, Adriaens E, Ramaeckers F, Bottenberg P (2015) The Evaluation of Sodium Lauryl Sulphate in Toothpaste on Toxicity on Human Gingiva and Mucosa: A 3D in vitro Model. Dentistry 5: 325. doi:10.4172/2161-1122.1000325

the toxicity potential of toothpaste formulations. Simultaneous histological evaluation is therefore mandatory for accurate toxicity assessment. Toothpastes containing SLS react different. This was clearly demonstrated for all endpoints. In order to validate the assay as a valid alternative to animal models, other substances have to be evaluated to substantiate the predictive value of both tissue models and experimental protocols used.

\section{Clinical Relevance}

Based on the findings of the study, we can make following recommendations. Usage of large amount of toothpaste sould be avoided (especially in children), toothpastes containing SLS are not intended to stay in the mouth and proper rinsing after brushing is advised, patients sensible to aphtuous laesions should be informed not to use toothpastes containing SLS.

Further research is needed to explain the appearance of apoptosis in these cell cultures after topical toothpaste application.

\section{Acknowledgements}

The authors wish to thank Mrs. M. Baekeland and Mr. R. De Zangher (CYTO VUB) for their excellent technical assistance in preparation of this article. Both authors B Vande Vannet, B De Wever, contributed equally to the realization \& publication of this paper.

\section{References}

1. Fischman SL (1997) Oral hygiene products: How far have we come in 6000 years? Periodontol 2000 15: 7-14.

2. Addy M, Moran J, Wade W (1994) Chemical plaque control in the prevention of gingivitis and periodontitis. In: Lang NP, Karring T (Eds.), Proceedings of the 1st European workshop on Periodontology. Quintessence Publishing Company, London.

3. Wulknitz P (1997) Cleaning power and abrasivity of European toothpastes. Adv Den Res 11: 576-579.

4. British Standards Institution (1981) Specification for toothpastes, BS 5136: 1981.

5. International Organization for Standardization (1995) Dentistry - Toothpaste: Requirements, test methods and marking. ISO 11609: 1995.

6. Lindhe J, Karring T, Lang NP (2003) Clinical Periodontology and implant dentistry. $\left(4^{\text {th }}\right.$ edn), Blackwell Munksgaard, Copenhagen.

7. Davis WB (1980) Cleaning and polishing the teeth by brushing. Community Dent Oral Epidemiol 8: 237-243

8. Forward GC, James AH, Barnett P, Jackson RJ (1997) Gum health products: what is in them and why? Periodontol 2000 15: 32-39.
9. Jenkins S, Addy M, Newcombe R (1991) Triclosan and sodium lauryl sulphate mouth rinses. (II). Effects on 4-day plaque re-growth. J Clin Periodontol 18 145-148.

10. Jenkins S, Addy M, Newcombe R (1991) Triclosan and sodium lauryl sulphate mouth rinses (I). Effects on salivary bacterial counts. J Clin Periodontol 18 $140-144$.

11. Moran J, Addy M, Newcombe R (1988) The antibacterial effect of toothpastes on the salivary flora. J Clin Periodontol 15: 193-199.

12. Baert JH, Veys RJ (1997) Triclosan inhibits sodium lauryl sulphate-induced changes in expression of cytokeratin genes in hamster check pouch epithelium. J Oral Pathol Med 26: 181-186.

13. Babich H, Babich JP (1997) Sodium lauryl sulfate and triclosan: in vitro cytotoxicity studies with gingival cells. Toxicol Lett 91: 189-196.

14. Veys RJ, Barkvoll P, De Boever J, Baert JH (1992) Possible side effects of sodium lauryl sulphate especially on oral tissues. J Head Neck Pathol 11: 8184.

15. Herlofson BB, Barkvoll P (1993) Desquamative effect of sodium lauryl sulphate on oral mucosa. A preliminary study. Acta Odontol Scand 51: 39-43.

16. Babich H, Zuckerbraun HL, Barber IB, Babich SB, Borenfreund E (1996) Cytotoxicity of sanguinarine chloride to cultured human cells from oral tissue. Pharmacol Toxicol 78: 397-403.

17. De Wever B, Charbonnier V (2002) Using tissue engineered skin to evaluate the irritation potential of skin care products. Cosmet Toilet 117: 28-36.

18. Nguyen DH, Beuerman RW, De Wever B, Rosdy M (2003) Three-dimensional construct of the human corneal epithelium for in vitro toxicology. Salem $\mathrm{H}$, Katz $S$ (eds.) In: Alternative toxicological Methods. CRC Press.

19. Wisse $E$ (1970) An electron microscopy study of the fenestrated endothelia lining of rat liver sinusoids. J Ultrastruct Res 31: 125-150.

20. Vande Vannet B, Mohebbian N, Wehrbein H (2006) Toxicity of used orthodontic archwires assessed by three-dimensional cell culture. Eur J of Orthod 28: 426432.

21. Vande Vannet B, Hanssens JL, Wehrbein H (2007) The use of threedimensional oral mucosa cell culture to assess the toxicity of soldered and welded wires. Eur J Orthod 29: 60-66.

22. Vande Vannet BM, Hanssens JL (2007) Cytotoxicity of two bonding adhesives assessed by three-dimensional cell culture. Angle Orthod 77: 716-722.

23. Prencipe M, Zupan A, Dovesi R, Apr E, Saunders VR (1995) Ab initio study of the structural properties of $\mathrm{LiF}, \mathrm{NaF}, \mathrm{KF}, \mathrm{LiCl}, \mathrm{NaCl}$, and $\mathrm{KCl}$. Phys Rev $\mathrm{B}$ Condens Matter 51: 3391-3396

24. Jeng JH, Hsieh CC, Lan WH, Chang MC, Lin SK, et al. (1998) Cytotoxicity of sodium fluoride on human oral mucosal fibroblasts and its mechanisms. Cell Biol Toxicol 14: 383-389.

25. Chang YC, Chou MY (2001) Cytotoxicity of fluoride on human pulp cell cultures in vitro. Oral Surg Oral Med Oral Pathol Oral Radiol Endod 91: 230-234. 